\title{
Studies on the broodstock production and larval rearing of Coral demoiselle Neopomacentrus nemurus (Bleeker 1857)
}

\author{
Manoharan Pillai Vasantha Rohini Krishna ${ }^{1}$ (D) | Mathavankonathu Kuttan Anil ${ }^{1}$ | \\ Pitchaimuthu Gomathi $^{1}$ | Padikkala Kandiyil Raheem ${ }^{1}$ | Neethu Raj Pushparajan ${ }^{1}$
}

Vizhinjam Research Centre of ICAR-Central Marine Fisheries Research Institute,

Thiruvananthapuram, Kerala, India

Correspondence

M. V. Rohini Krishna, TKM College of Arts

and Science, Kollam, Kerala, India.

Email: rohini.krishna09@gmail.com

\begin{abstract}
Steps taken for broodstock development of Neopomacentrus nemurus, Coral demoiselle (Bleeker, 1857) in a hatchery, its spawning and development of egg to the juvenile stage are described. Among the three treatments tried, only the trial using Parvocalanus crassirostris nauplii as the first diet helped in the development of larvae. Larval and post-larval growth was studied for a period of 65 days post hatch. The larva measured 2-2.4 $\mathrm{mm}$ in total length at the time of hatching. The mouth size of larva at the time of hatching measured $237.92 \mu \mathrm{m}$. By the 5th day, the width of the larval body had significantly increased. All the fins were conjoined, except for the caudal fin which had begun its appearance on the 2 nd day itself. The digestive system was functional by the 5th day and the copepod remains were seen in the digestive tract. The larva metamorphosed by the 15th day with fully developed fins and fin rays. On the 20th day, the larval body had begun to display signs of fin pigmentation. The larva assumed adult pigmentation by the 35th day. By the 65th day, the larva grew to a total length of about $27 \mathrm{~mm}$ and weighed about $0.56 \mathrm{~g}$.
\end{abstract}

KEYWORDS

broodstock development, Damselfish, larval rearing, Neopomacentrus nemurus, Pomacentridae

\section{1 | INTRODUCTION}

The marine ornamental fish industry depends mostly on the organisms harvested from the wild (Wabnitz, Taylor, Green, \& Razak, 2003). The only solution to this problem is aquaculture, which could provide a growing proportion of marine ornamental fish in the near future (Molina \& Segade, 2012). Out of the 1,000 species of coral reef fish traded (Green, 2003), only 51 have been cultured in captivity for the aquarium trade (Arvedlund, McCormick, \& Ainsworth, 2000) and a very few in commercial quantities. Approximately 30 million marine reef fish belonging to roughly 1,800 different species are commercialized every year worldwide (Rhyne et al., 2012; Thornhill, 2012; Wabnitz et al., 2003). In 2013, Singapore had exported around US\$ 56 million worth of ornamental fish to over 80 countries (FAO, 2014). Over the years since 1985, its international trade has shown an increasing trend (Moorhead \& Zeng, 2010), with an average growth rate of approximately $14 \%$ per year with an estimated wholesale trade of nearly US\$ 1 billion and retail trade of about US\$ 3 billion (Olivotto et al., 2005). Large-scale destruction of coral reefs by anthropogenic activities has taken its toll on the fragile coral reef ecosystem that houses many of these fish. In view of this, many captive breeding programmes have been initiated for minimizing harvesting from the wild and maximizing ex-situ production of these fish. It can be said that the marine ornamental fish industry is still in its infancy and many hazards have yet to be faced before we could safely say that we have reached a significant milestone in this field. The constraints faced by this industry are so many that we cannot pinpoint a single factor, many fish need large tanks to spawn while others have to be provided with suitable photoperiods and temperatures (Holt \& Riley, 2001) and specific environmental conditions. Some others need hormones to make them spawn (Moe, 1997). But one advantage that Pomacentrids have over most other 
ornamental fish species is that they need not be subjected to the other techniques mentioned before. Pomacentrids are continuous spawners and they lay eggs if provided with the proper water quality conditions and food, the only contradiction to this being members of the genus Abudefduf. Even though reports of successful breeding of Pomacentrids of genera Amphiprion and Premnas have been published, successful larval rearing of damselfish is still in its infancy. There are only a few reports regarding the successful larval development of many damselfish such as Abudefduf saxatilis (Alshuth, Tucker, \& Hatley, 1998; Wittenrich, Turingan, \& Cassiano, 2012), Microspathodon chrysurus (Potthoff, Kelley, Saksena, Moe, \& Young, 1987), and Pomacentrus amboinensis (Murphy, Leis, \& Kavanagh, 2007). Breeding and larviculture of the sapphire devil damselfish Chrysiptera cyanea were carried out by Gopakumar, Santhosi and Ramamurthy (2009). A comprehensive study on the breeding of $N$. nemurus (Coral demoiselle) is yet unavailable. This study is an attempt to throw light on the broodstock development, larval rearing, and larval development of $N$. nemurus.

The Coral demoiselle, $N$. nemurus is distributed throughout the Indian Ocean and Western Central Pacific. Adults inhabit lagoon and inshore coral reefs, and they are found in aggregations of coral reefs from where they feed on zooplankton (Myers, 1991). They occur at a depth of about 1-10 m (Allen, 1991). The fish has a greyish body with transparent pectoral and pelvic fins. The spinous dorsal is grey in colour and the soft dorsal is yellow, same is the case of the anal and caudal fins.

\section{2 | MATERIALS AND METHODS}

\section{1 | Broodstock development}

Eight sexually mature fish of $N$. nemurus measuring $6.5-10 \mathrm{~cm}$ were collected from the wild.

The collection was made from Vizhinjam along the south-west coast of India in September, 2016 by skin diving using scoop net. They were transported to the hatchery of Vizhinjam Research Centre of ICAR-Central Marine Fisheries Research Institute, in jerrycans of $20 \mathrm{~L}$ capacity in aerated seawater using battery operated aerators.

\section{2 | Broodstock tank}

The fish were stocked in a rectangular fibre-reinforced plastic (FRP) tank of $500 \mathrm{~L}$ capacity and water was continuously filtered using an in-situ biological filter of volume $21 \mathrm{~L}$. Coral rubble is used as the biological filter material. Coral containing numerous pores provide a large surface area for nitrifying bacteria to colonize which helps in the effective removal of ammonia produced by the fish. The area being near the equator, the photoperiod during the rearing period was of $12 \mathrm{hr}$ $\mathrm{L}: 12 \mathrm{hr} \mathrm{D}$ and no photoperiod manipulation was done. The tank is kept in a place where there is minimum disturbance. Physico-chemical parameters, such as salinity, $\mathrm{pH}$, dissolved oxygen, water temperature, and $\mathrm{NH}_{3}$, were checked twice in a week using standard methods. For maintaining water quality in the rearing tanks, about $10 \%$ of rearing water along with excretory matter and excess feed was siphoned off daily and the water was replaced with fresh seawater. The tank was provided with earthen pots and polyvinyl chloride (PVC) pipes as a substratum for laying eggs. The fish were fed four times a day as per the schedule: pellet feed at $10.00 \mathrm{hr}$; boiled mussel meat at $12.00 \mathrm{hr}$ and $14.00 \mathrm{hr}$, and Artemia at $16.00 \mathrm{hr}$.

Observations on the courtship, parental care, and response to nest disturbance were carried out twice daily for a period of 4 months. In order to assess the behaviour, F1 generation N. nemurus were kept in three aquarium tanks and observations were made. The observations were carried out during 10-11 a.m. and 4-5 p.m. for the presence of any new egg clutches. Observations were made for more than $500 \mathrm{hr}$. Three months of observation for a period of $2 \mathrm{hr}$ a day were made for making possible conclusions. To monitor the embryonic development, fertilized eggs from three different clutches were taken out three times. It was difficult to observe the frequency as two fish were laying eggs. The characters of newly spawned and fertilized egg were noted for a period of 3 days. The larval development was monitored by sampling five numbers of fish larvae every day until the 5th day and on $10,15,20,30,40,50$, and $65 \mathrm{dph}$ for growth measurements. The embryonic development was monitored using a Leica DMCS research microscope. Water was taken in a beaker and the number of larvae, their behaviour, and feed availability were observed. The availability of adult copepods, number of rotifers, and number of Artemia were counted by taking subsamples and the feeding was adjusted accordingly during the different stages of larval rearing according to the schedule given in the table. The larval development was monitored using a Leica S8APO stereozoom microscope. From the measurements obtained, the mean and standard deviation were calculated.

\section{3 | Live feed culture}

Live feeds, such as phytoplankton, rotifer, marine zooplankton including copepods, and Artemia, were used for the larval rearing experiments. For feeding copepod culture and for maintaining green water in the rearing tanks, the stock culture of algae viz., Nannochloropsis oculata and Isochrysis galbana was maintained in a stock culture room at $24^{\circ} \mathrm{C}$ in $100 \mathrm{ml}$ to 3-L flasks and then the cultures were upscaled to 20-L carboys for feeding. The copepod Parvocalanus crassirostris was cultured using N. oculata and I. galbana. Rotifer Brachionus plicatilis was cultured using algae N. oculata. Rotifers were enriched using Algamac 2000 (Aquafauna Bio-Marine, USA).

\subsection{Larviculture tank}

Three treatments were tried for rearing the larvae and about 400 damselfish larvae were used for each treatment in a rectangular $500-L$ FRP tank with light blue colour $(100 \mathrm{~cm}$ length $\times 80 \mathrm{~cm}$ breadth $\times 60 \mathrm{~cm}$ depth). Larvae were stocked at a rate of 10 per ml. Seawater used was filtered using a series of $10-, 5-$, and $2-\mu \mathrm{m}$ cartridge filters and mild aeration was given throughout the rearing period. 
Three feeding trials were conducted with copepod (T1), rotifer with and without enrichment (T2 and T3) and in all three treatments, the green water technique was employed. Algal cell density used for the experiment ranged from $1.4 \times 10^{6}$ to $9 \times 10^{6}$ per $\mathrm{ml}$. All the three tanks were supplied with the algae $N$. oculata and I. galbana (3:1) up to the 20th day. In (T1), the tanks contained adults of $P$. crassirostris. The number of adult copepods was maintained at about 0.7-0.9 per $\mathrm{ml}$ respectively. The presence of adult copepods will ensure the smallest naupliar stage just hatched out from egg available to the altricial fish larvae. The tanks of (T2) contained enriched rotifer B. plicatilus, size $170.532-213.565 \mu \mathrm{m}$ (3-6 per ml). The tanks of (T3) contained rotifer $B$. plicatilus (3-6 per $\mathrm{ml}$ ).

For feeding experiments, the larvae were divided and from day 0 to 8 the first group, T1 was fed with the copepod P. crassirostris nauplii and from the 6 to 18th day on rotifer B. plicatilus (3-6 per $\mathrm{ml}$ ) and then from 16th day on Artemia nauplii. Boiled mussel meat was given to the larvae from the 35th day onwards. In T2, the larvae were fed with enriched B. plicatilus from 1 to 5 dph. In T3, the larvae were fed from day 1 to 5 on B. plicatilus (Table 1). Treatments were repeated three times. The data were analysed and the result was expressed as mean $\pm S D$ of the data (Table 2).

\section{RESULTS}

Fish started spawning after 62 days of stocking in the broodstock tanks and the spawning took place in the morning hours 107.00 $10.00 \mathrm{hr}$ ). The water quality parameters of the brood stock were: nitrate level of less than $18 \mathrm{ppm}$, nitrite and ammonia levels of less than $0.01 \mathrm{ppm}$, temperature, salinity, and $\mathrm{pH} 27 \pm 02^{\circ} \mathrm{C}, 30-32 \mathrm{ppt}$, and $8-8.2$ respectively.

\section{1 | Reproductive behaviour}

The fish exhibited territorial behaviour and were observed to attack other fish if they came close to their eggs. The fish preferred to lay the eggs on the sides of the tank other than the earthen pots or PVC pipes (Figure 1). N. nemurus is sexually monomorphic and the male parent exhibited a high degree of parental care for the eggs, such as fanning the eggs with the pectoral and caudal fins and removing the infected eggs with the mouth (Figure 2). The fish also tend to consume the egg clutch if it was disturbed. The fertilized eggs were transparent, capsule shaped, demersal, and contained oil globules. The eggs measured 1,168-1,156 $\mu \mathrm{m}$ in length and 380$400 \mu \mathrm{m}$ in width. The yolk length was found to be $725 \mu \mathrm{m}$ on the first day after spawning. The egg clutches contained 1,500-1,800 eggs with an average of $1653.36 \pm 133.55$ per spawn.

The fish exhibited a high spawning frequency with an average of 7-8 per month, indicating that it spawns on every $3 / 5$ th day. In the beginning, the spawning frequency was observed to be 2-3 times per month with no specific interval. The highest spawning frequency was observed during the month of March. Hatching took place in the early evening at about 19.00-19.30 hr. The larvae were collected from the broodstock tank and transferred to the larval rearing tanks with the help of a small trough by concentrating the larvae to one area using a torch as the larvae are photopositive in nature. The hatching rate was found out to be $98 \%$.

\section{2 | Larval development}

Hatching usually occurred on the 3rd day of incubation. Eggs were encased in a transparent capsule, the colour of which changed from transparent to yellowish in the case of spoilage and the spoiled eggs

TAB LE 1 Feeding schedule of hatchery-reared Neopomacentrus nemurus

\begin{tabular}{|c|c|c|c|c|c|c|c|c|c|c|c|c|c|c|c|c|c|c|c|c|c|c|c|c|}
\hline \multirow[b]{2}{*}{ Days } & \multicolumn{24}{|c|}{ Feeding schedule of hatchery-reared Neopomacentrus nemurus } \\
\hline & 01 & 2 & 3 & 4 & 5 & 6 & 7 & 8 & 9 & 10 & 12 & 14 & 16 & 18 & 20 & 25 & 30 & 35 & 40 & 45 & 50 & 55 & 60 & 65 \\
\hline \multicolumn{25}{|l|}{ Treatment 1} \\
\hline \multicolumn{25}{|l|}{$\begin{array}{l}\text { Parvocalanus nauplii } \\
\text { (0.7-9 per ml) }\end{array}$} \\
\hline \multicolumn{25}{|l|}{ Artemia nauplii } \\
\hline \multicolumn{25}{|l|}{ Boiled mussel meat } \\
\hline \multicolumn{25}{|l|}{ Treatment 2} \\
\hline \multicolumn{25}{|l|}{ Nanochloropsis and Isochrysis } \\
\hline \multicolumn{25}{|l|}{ Nanochloropsis and Isochrysis } \\
\hline $\begin{array}{l}\text { Brachionous plicatilus (3-6 per } \\
\text { ml) unenriched }\end{array}$ & & & & & & & & & & & & & & & & & & & & & & & & \\
\hline
\end{tabular}


TABLE 2 Morphometric data of hatchery-reared Neopomacentrus nemurus. First line (mean $\pm S D$ ), second line - range

\begin{tabular}{|c|c|c|c|c|c|c|}
\hline Days post hatch (dph) & Total length (mm) & Standard length (mm) & Head length (mm) & Head width $(\mathrm{mm})$ & Body width (mm) & Eye diameter $(\mathrm{mm})$ \\
\hline \multirow[t]{2}{*}{1} & $2.18 \pm 0.15$ & $1.84 \pm 0.11$ & $0.67 \pm 0.04$ & $0.47 \pm 0.04$ & $0.23 \pm 0.04$ & $0.17 \pm 0.04$ \\
\hline & $2-2.4$ & $1.8-2$ & $0.6-0.7$ & $0.4-0.5$ & $0.2-0.3$ & $0.17-0.2$ \\
\hline 5 & $2.7-3.4$ & $2.3-3.1$ & $0.8-0.86$ & $0.6-0.9$ & $0.5-0.7$ & $0.15-0.35$ \\
\hline 10 & $4.94 \pm 0.30$ & $4.32 \pm 0.49$ & $1.36 \pm 0.15$ & $1.33 \pm 0.18$ & $1.20 \pm 0.28$ & $0.54 \pm 0.11$ \\
\hline 15 & $6.8-7.5$ & $5.6-6.5$ & $1.9-2.2$ & $1.6-2.1$ & $1.6-2.4$ & $0.6-0.9$ \\
\hline \multirow[t]{2}{*}{20} & $9.7 \pm 0.67$ & $8.1 \pm 0.99$ & $3.5 \pm 0.34$ & $3.2 \pm 0.33$ & $3 \pm 0.41$ & $1.1 \pm 0.71$ \\
\hline & $9.5-11.2$ & $7.2-8.8$ & $2.8-3.5$ & $2.6-3.4$ & 2.7-3.7 & $1-1.5$ \\
\hline 30 & $13.06 \pm 1.65$ & $10.3 \pm 1.64$ & $4.14 \pm 0.34$ & $4.32 \pm 0.37$ & $3.96 \pm 0.69$ & $1.44 \pm 0.34$ \\
\hline \multirow[t]{2}{*}{50} & $20.3 \pm 4.0$ & $17.6 \pm 2.1$ & $5.12 \pm 0.5$ & $5.49 \pm 0.4$ & $5.6 \pm 0.7$ & $2.1 \pm 0.2$ \\
\hline & $15.5-25$ & $15-20$ & $4.4-5.6$ & $5-6.04$ & $4.7-6.3$ & $1.9-2.3$ \\
\hline \multirow[t]{2}{*}{65} & $27 \pm 2.5$ & $18 \pm 1.4$ & $6 \pm 0.67$ & $5.9 \pm 0.34$ & $6.18 \pm 0.57$ & $2.3 \pm 0.16$ \\
\hline & $24-30$ & $16-20$ & $5.2-6.8$ & $5.5-6.4$ & $5.6-7$ & $2.1-2.5$ \\
\hline
\end{tabular}

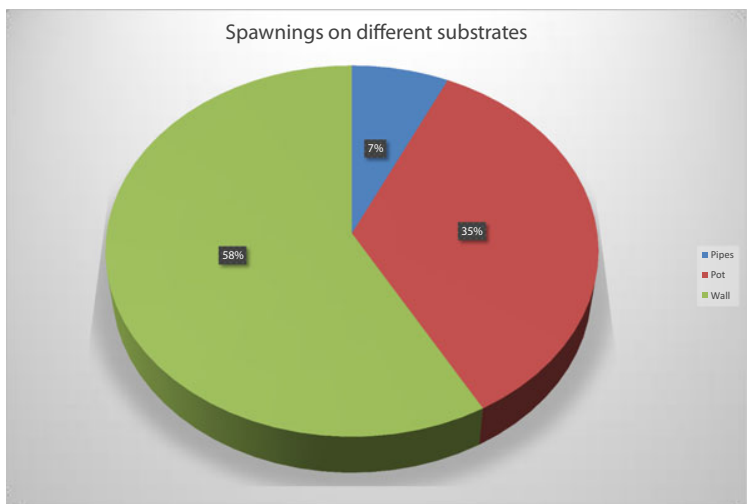

FIGURE 1 Spawning preference of Neopomacentrus nemurus on various substrates

also exhibited a cloudy appearance. The egg capsule did not exhibit any external morphological alterations during development. In addition to the yolk, the eggs were provided with oil globules which equipped them with the capacity for buoyancy and enabled them to stand upright while attached to the substratum. The number of oil droplets varied from 1 to several. On the first day as a consequence of meroblastic discoidal cleavage, the yolky part of the egg remained uncleaved while the cleavage and micromere formation occurred in the blastodisc where the cytoplasm was confined (Figure 3). On the second day, rudiments of the head fold and tail fold were visible in the embryo. The larval body showed clear signs of development with the appearance of melanophores over the tail region. The yolk had

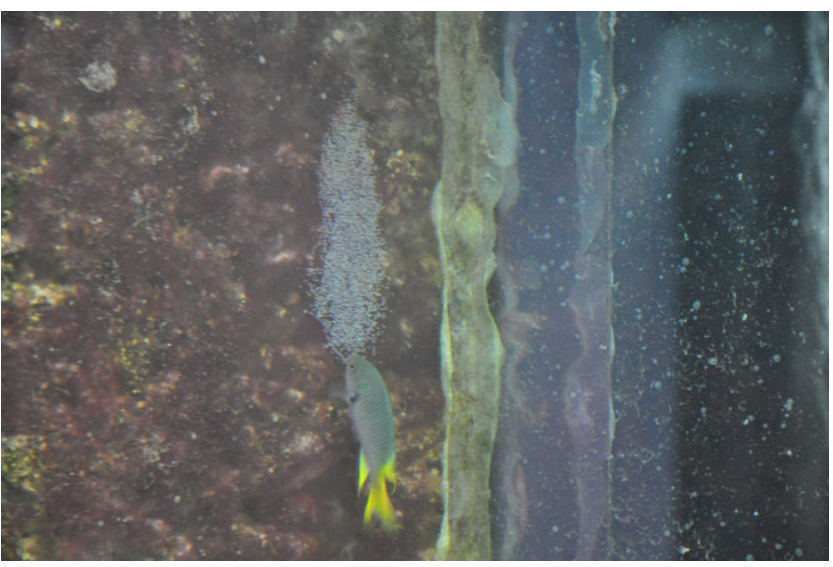

FIGURE 2 Parental care in Neopomacentrus nemurus male

shrunk to half of its normal size. On the 3rd day at the time of hatching, the larval body was almost fully formed. The optic vesicles had completed its development followed by the appearance of the retina. The eyes showed a bluish-silver colour, the tail was totally curved and extended to the head, these two signs indicated that the larvae were about to hatch. The larva had developed an efficient circulatory system, which was evident by the heartbeat. The larval body showed signs of segmentation which was evident by the appearance of paired myomeres. The yolk had shrunken and now occupied one third of the egg, the larval body was transparent except for the presence of a yellow colouration in the gut and melanophores (Figure 4). The larval body occupies the whole of the 


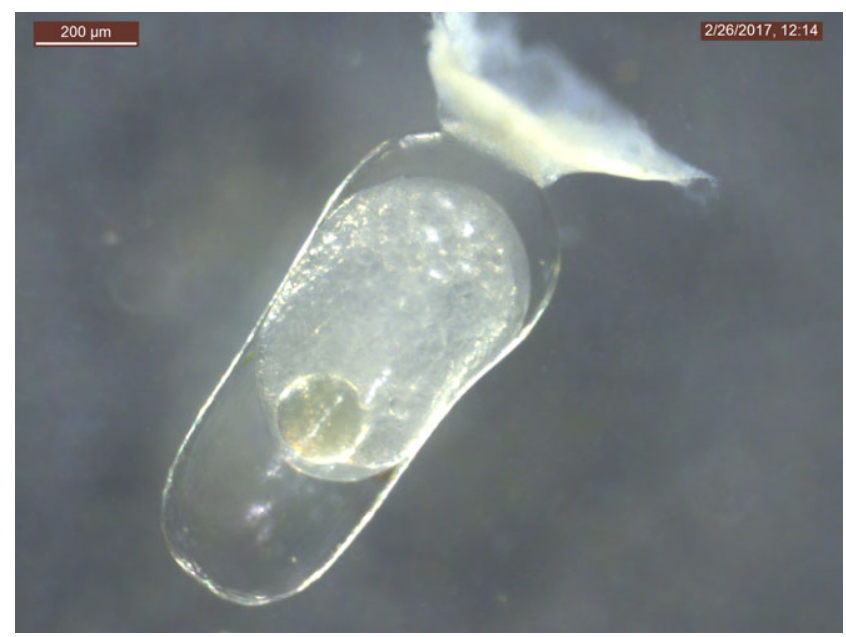

FIGURE 3 Neopomacentrus nemurus egg 1st day

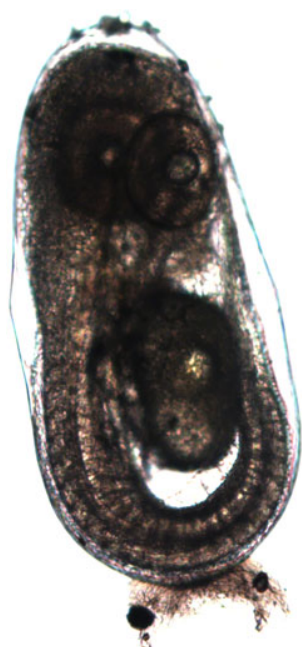

FIGURE 4 Neopomacentrus nemurus egg just before hatching

capsule and then breaks it off by vigorous wriggling movements at the end of incubation period (5 days).

\section{3 | Feed management}

In T1, the presence of $P$. crassirostris adults ensures that the smallest possible live stages of copepod nauplii are available to the newly hatched larvae. In this treatment, the larvae survived. In T2 and T3, the larvae that survived with the available yolk reserve until the 4 5th day perished. The larvae in T1 showed active swimming movements, and the larvae also appeared to favour the sides of the tank where the copepods were concentrated. The microscopic observation of the dissected stomach on the 4th day revealed the presence of copepod nauplii. In T2, when the larvae were given the enriched rotifer B. plicatilus of size range (170.532-213.565 $\mu \mathrm{m})$, they did not feed on rotifers and this resulted in the total mortality of all larvae in the tank by the 4th-5th day. Similar observations were made in T3 fed with B. plicatilis without enrichment.

The larva was transparent and measured 2-2.4 mm in total length at the time of hatching. Since the larva was altricial and with a mouth gap of about $237.92 \mu \mathrm{m}$, it was provided with a small but regressed yolk sac to meet the requirements of its early development. Although immediately after hatching, the larvae did not feed on any copepod nauplii, it consumed the algae provided in the tank and the dissection of the larval body helped to confirm the same. The first nauplii of copepods are in the range of 50-100 $\mu \mathrm{m}$, which makes it suitable food for the damsel fish larvae. The eye is well developed in the larvae and is found protruding from the two sides of the head, which are an indication of its carnivorous and voracious habit (Figure 5). The melanophores, which were making their appearance when the fish was in the embryonic stage, have established their presence now. The larva follows a developmental pattern characterized by 4-5 melanophores along the head and with melanophores below the ventral midline of the body which are not much developed as that of the head. They were about 13 in number. All the fins are fused to form a single fin fold which surrounds the body (Figure 6).

By the 5th day, the width of the larval body had drastically increased. The pigmentation on the larval body was well evident in the opercular region which was transparent at first and then steadily attained a yellow colour. The drastic increase in pigmentation was also evident in the ventral midline. All the fins were conjoined except for the caudal fin which had begun its appearance on the 2nd day itself. The larval body did not exhibit any colouration and remained transparent. The dissection of the digestive tract on the 5 th day revealed the presence of a well-developed digestive system, which was supported by the fact that copepod nauplii were obtained from the larval stomach. By the 7th and 8th day, one of the notable changes, which occurred in the larval body, was the infiltration of the yellow pigmentation which was restricted to the gut into the orbital region (Figure 7).

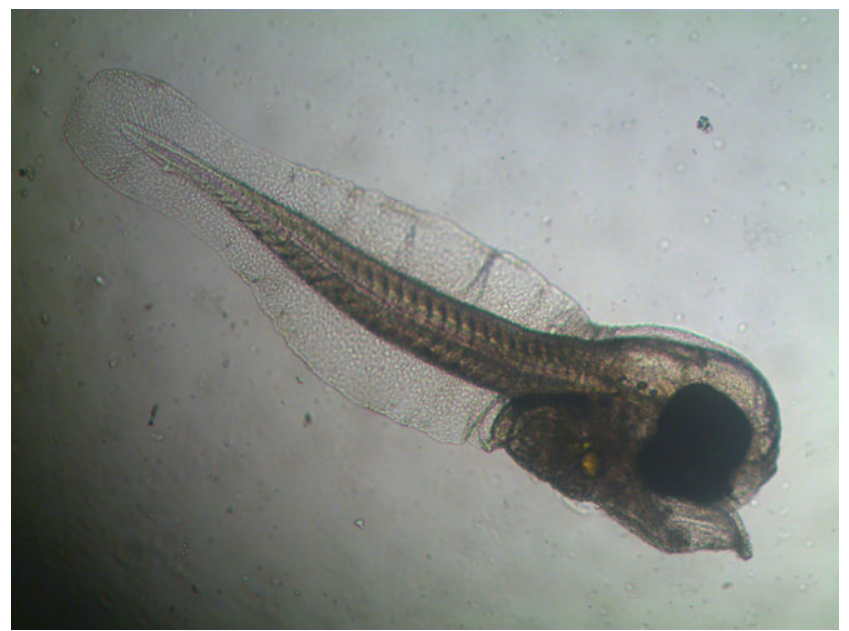

FIGURE 5 Neopomacentrus nemurus newly hatched larvae 


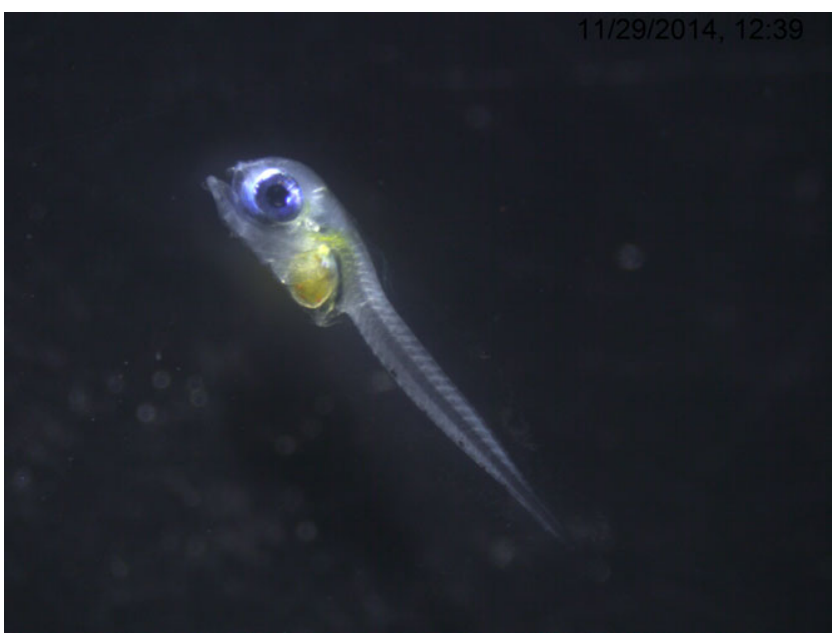

FIGURE 6 Neopomacentrus nemurus 3rd day larvae

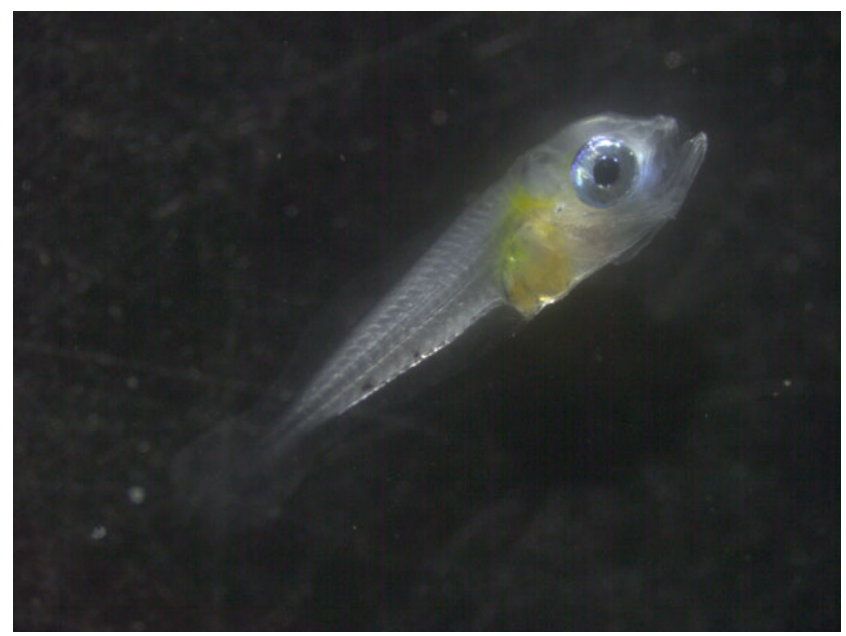

FIGURE 7 Neopomacentrus nemurus 7th day larvae

On the 10th day, the fin separation was complete during which the larval body showed the appearance of fins and fin rays. The soft dorsal had separated from the spinous dorsal fin. Many of the specimens had undergone notochord flexion. Pigmentation of the deep pre-anal body was characterized by extensive scattered stellate melanophores. Pigmentation of the stomach, operculum, and pelvic fins did not show any notable difference. There was an increase in the number of caudal fin rays, the larva showed increased pigmentation and decreased transparency. A slightly yellowish colour was observed in the region of the body where the melanophores were present (Figure 8).

The larvae developed into subadult fish by the 15th day with fully developed fins and fin rays. They showed vigorous swimming movements and voracious feeding. The melanophores present over the body varied in size and distribution. Stellate and stellate reticulate granules were present above the eyes, the snout and upper jaw,

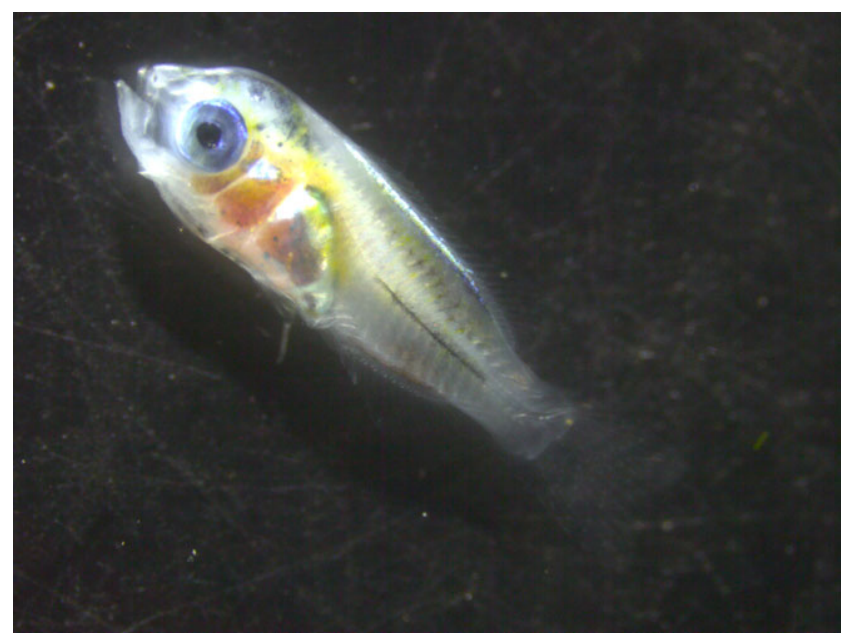

FIGURE 8 Neopomacentrus nemurus 10th day larvae

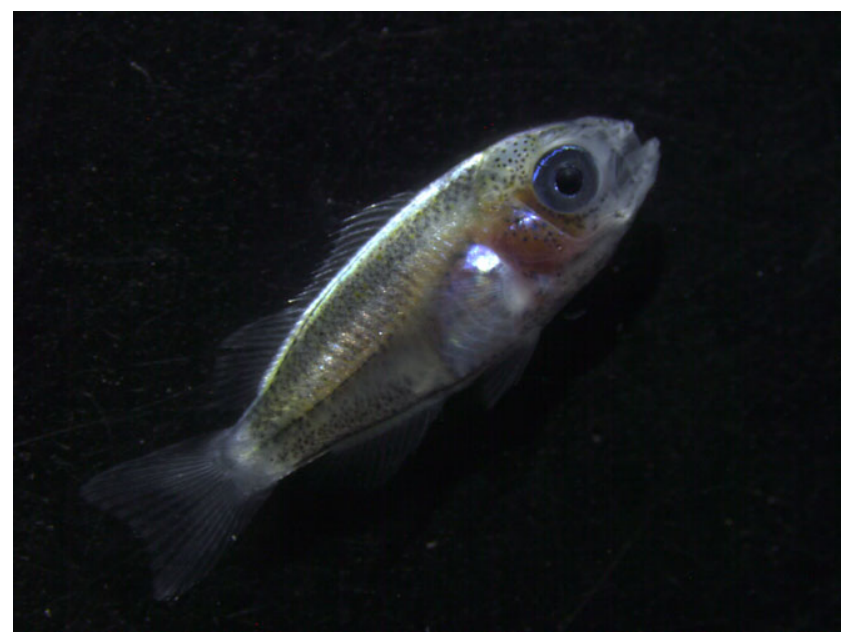

FIGURE 9 Neopomacentrus nemurus 15th day larvae

but punctate melanophores were predominant in the gut and anal fin (Figure 9).

On the 20th day, the larval body had begun to display signs of fin pigmentation. Black pigmentation had begun to develop in the centre of the spinous dorsal fin. The rest of the fins were transparent. The depth of the larval body increased conspicuously. Punctate melanophores were present on the ventral midline (Figure 10).

The larva assumed adult pigmentation on the 35th day and by then, the larva resembled the adult in all other aspects except size. Now the fish had attained the characteristic greyish colour of the adult on the anterior region of the body, whereas the posterior region exhibited a yellowish colouration which extended to the two sides of the caudal fin, the middle of the caudal fin was more or less transparent. The pectoral and anal fins were transparent with some yellow pigment granules. The spinous dorsal possessed black 


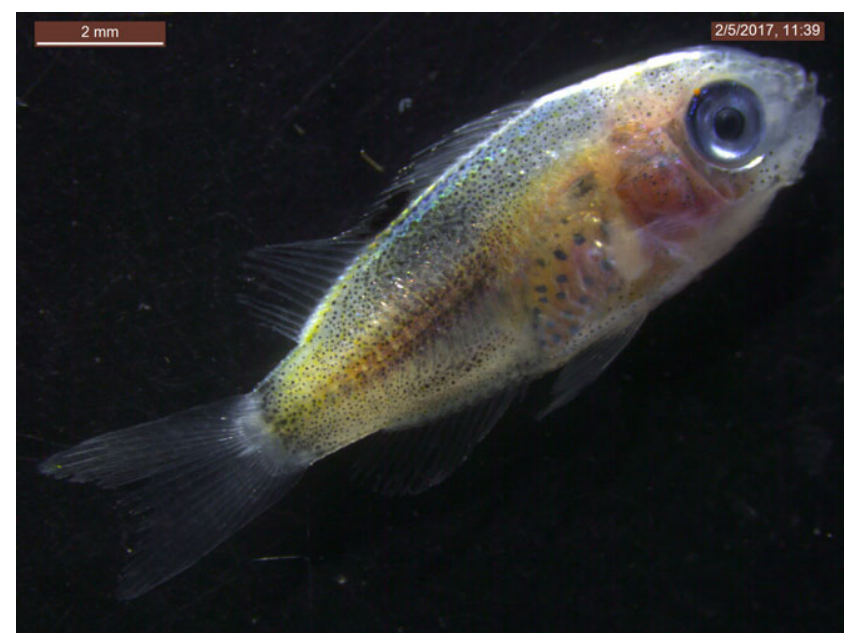

FIGURE 10 Neopomacentrus nemurus 20th day larvae

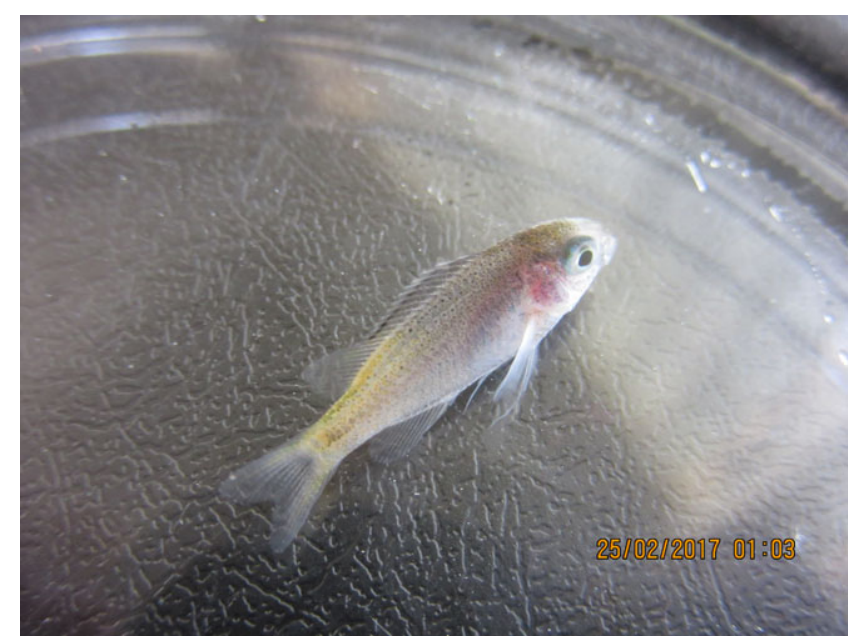

FIGURE 11 Neopomacentrus nemurus 35th day larvae [Colour figure can be viewed at wileyonlinelibrary.com]

pigment granules whereas the soft dorsal had yellowish granules (Figure 11).

On the 50th day, the pigmentation of the body showed some change in which the anterior part of the body exhibited a greyish colouration and the posterior region exhibited a bluish-grey colour, the fin pigmentation which was restricted to broken pigments changed into one with continuous colouration. The soft dorsal fins exhibited a continuous yellow colour, while yellow colour was also prominent on the caudal peduncle and the caudal fins (Figure 12).

On the 65th day, the pigmentation pattern was unchanged, but the difference in colouration between the anterior and posterior sides decreased notably. From now on, the larva did not undergo any change in skin and fin pigmentation but only increased in body mass (Figure 13). By the 65th day, the larva grew to a total length of about $27 \mathrm{~mm}$ and weighed about $0.56 \mathrm{~g}$ (Figure 14). The growth

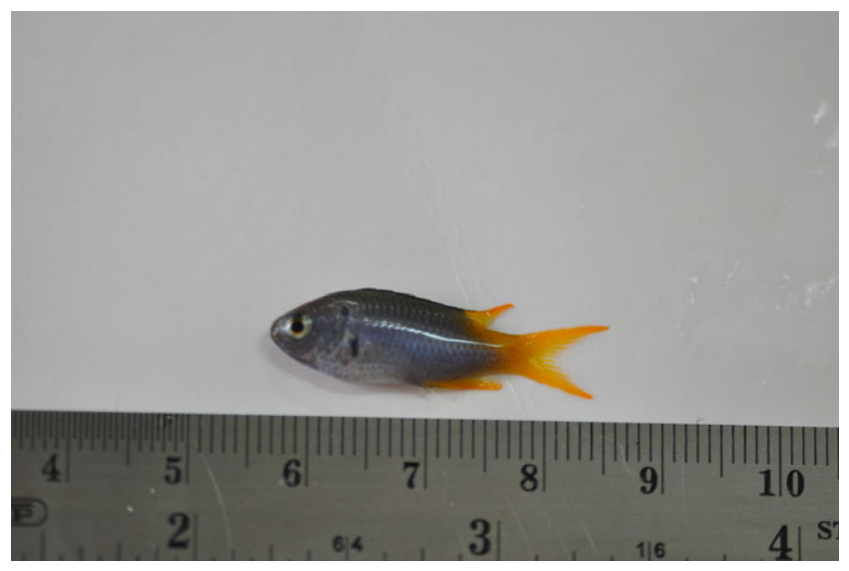

FIGURE 12 Neopomacentrus nemurus 50th day larvae

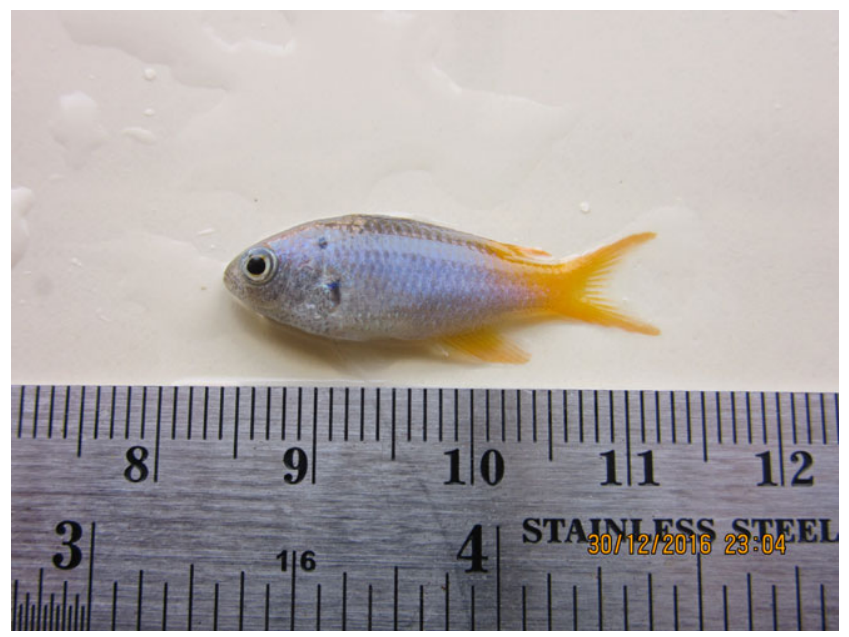

FIGURE 13 Neopomacentrus nemurus 65th day larvae

in terms of the total length showed a steady increase, whereas the weight increase was slow until 20 days thereafter it increased at a higher rate. The average growth of $N$. nemurus in length and weight is depicted in the table. The average survival rate was found to be $4.9 \pm 2.0$ from three trials (Figure 15).

In order to assess the sex ratio, 10 fish of F1 generation (9month-old specimens), which started laying eggs from 177 days which were kept in the rearing tank, were sacrificed and it was observed that two mature males, two mature females, and two maturing females were present in the tank. There were two active females and one active male in the tank. The active male was guarding the eggs and two active females were depositing the eggs.

\section{DISCUSSION}

The number of marine ornamental fish species, which are bred on a commercial scale, is very much limited in number. The hatchery production of marine ornamental fish is subjected to many constraints 


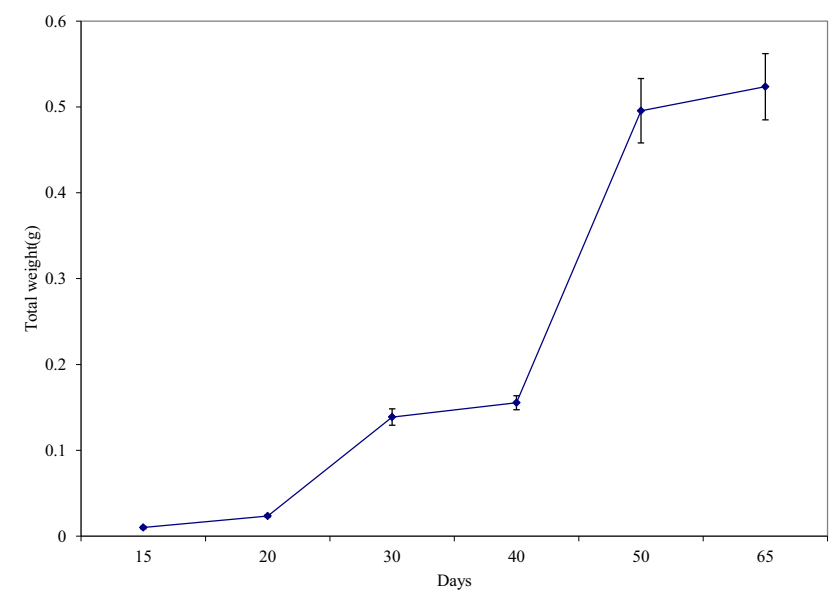

FIGURE 14 Growth in terms of weight of hatchery produced Neopomacentrus nemurus

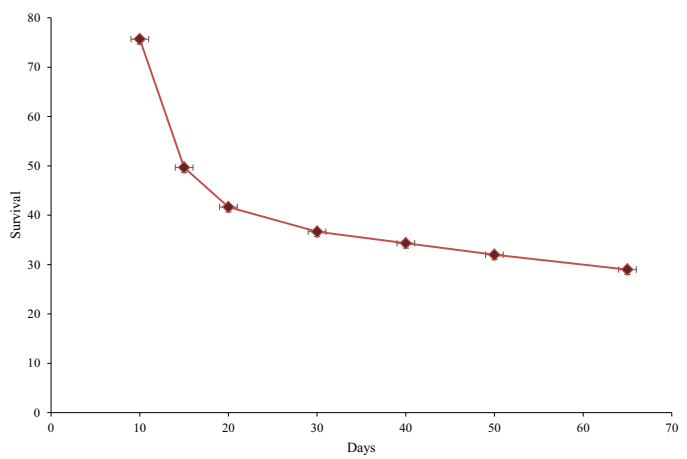

FIGURE 15 Average larval survival rate of Neopomacentrus nemurus

such as difficulty in producing good quality gametes and producing a large number of larvae which will undergo metamorphosis into good quality juveniles (Holt, 2003). It is now evident that even before the commencement of captive spawning, different factors can affect the quality of the larvae, the notable being broodstock genetics (Green \& McCormick, 2005), nutrition (Ostrowski \& Laidley, 2004), age (Berkeley, Chapman, \& Sogard, 2004), and environmental-induced stress (Schreck, Contreras-Sanzhez, \& Fitzpatrick, 2001).

The water quality parameters in broodstock tank, such as temperature, salinity, $\mathrm{pH}$, ammonia, nitrite, and nitrate, were maintained to the optimum level. Nitrate of less than 18 ppm, nitrite and ammonia levels of less than $0.01 \mathrm{ppm}$ were always maintained in the tanks. Temperature, salinity, and $\mathrm{pH}$ in the breeding tanks were maintained at $27 \pm 02^{\circ} \mathrm{C}, 30-32 \mathrm{ppt}$, and 8-8.2 respectively. Temperature in the broodstock tanks must be maintained at an optimum as the temperature can accelerate or retard the development rate of the embryo. (Bermudes \& Ritar, 1999; Das et al., 2006; Kazuyuki, Hisashi, \& Shogoro, 1988; Miranda, Cal, \& Iglesias, 1990; Moran, Smith, Gara, \& Poortenaar, 2007). Epinephelus coioides, which have very small larvae similar to those of $N$. nemurus, was successfully reared in a hatchery having water quality parameters: water temperature $26.0 \pm 0.8^{\circ} \mathrm{C}$, ammonia concentration $0.18 \pm 0.05 \mathrm{mg} / \mathrm{L}$, nitrite concentration $0.021 \pm 0.003 \mathrm{mg} / \mathrm{L}$, and pH $7.8 \pm 0.4$ (Yousif, Kumar, Balamurugan, Hozifa, \& Sagir, 2016).

Brood fish were fed four times a day with pellet feed, boiled mussel meat, and Artemia nauplii. This feeding schedule can be followed as such or can be subjected to slight variations. It is always recommended to feed the broodstock with a well-balanced compounded feed (Olivotto \& Geffroy, 2017). In Sunrise dottyback Pseudochromis flavivertex fish were fed twice a day using frozen adult Artemia, frozen plankton, and chopped fish and shrimps (Olivotto et al., 2006). In honeycomb grouper, Epinephelus merra the spawners were provided with fresh sardines on alternate days and squid meat (Jagadis, Ignatius, Kandasami, \& Khan, 2006).

Neopomacentrus nemurus performed spawning during the morning, while a similar behaviour was reported in the damselfish Neopomacentrus cyanomos (Rohini Krishna, Anil, Neethu Raj, \& Santhosh, 2016). But in Amblyglyphidodon leucogaster, the spawning occurred throughout the day (Goulet, 1995). The eggs were demersal and were deposited on the earthen pots, tiles, PVC pipes, filters, or sides of the tank. In natural habitat, they always deposit eggs over a certain substratum and the choice of the substratum varies with different species. In the case of $N$. nemurus, they always prefer to deposit eggs on the sea-floor or among coral masses. Whereas in the case of brown chromis, Chromis multilineata eggs were deposited in large masses on Sargassum (Myrberg, Brahy, \& Emery, 1967). Beaugregory damsel, Stegastes leucostictus deposited their eggs on empty conch shells or on the under surface of rocks, sometimes they also preferred Sea fans shells, cans, bottles, and other hard substrates (Brinley, 1939). From this, we can conclude that the availability of a suitable substrate is indispensable for spawning.

The spawning frequency in $N$. nemurus was found to be 7-8 per month, which is much higher when compared with other fish such as Premnas biaculeatus or Amphiprion nigripes (Anil, Santhosh, Prasad, \& George, 2012; Madhu, Madhu, \& Retheesh, 2012).

The incubation period of $N$. nemurus is 3 days, which is characteristic of damsel fish having small egg size, here they are about 1,168-1,156 $\mu \mathrm{m}$ long and 380-400 $\mu \mathrm{m}$ wide. Similar results were observed in C. cyanea by Gopakumar, Madhu, et al. (2009) in which the egg size measured from $1.3 \mathrm{~mm}$ in length and $0.6 \mathrm{~mm}$ in width. Species such as $A$. saxatilis have larger eggs (1,100-1,250 mm long and $650-670 \mathrm{~mm}$ wide) and have an incubation period of about 57 days (Alshuth et al., 1998; Thresher, 1984). Kavanagh (1996) recorded bigger eggs in Acanthochromis polycanthus, which measured $3.7-4.3 \mathrm{~mm}$ in length and $1.4-1.5 \mathrm{~mm}$ in width and they have an incubation period of about 16 days.

The larval body started forming from the 2 nd day of incubation onwards. The myomeres were visible from the 3rd day onwards. This development is noteworthy as muscle development can be taken as a measure of the morphological development and swimming ability (Fisher, Bellwood, \& Job, 2000).

For larval rearing, a rectangular FRP tank with light blue colour holding $400 \mathrm{~L}$ of seawater was used. Tank colour in the rearing tank may affect the feeding of marine fish larvae. In groupers, the tank colour preference is species dependent (Ma, Guo, Zhang, \& Bai, 
2013). There is paucity of literature to support the fact that colour of the larval rearing tank affects the larval survival in damsel fish. When A. saxatilis larvae were stocked in $120 \mathrm{~L}$ and $60 \mathrm{~L}$ tanks at a stocking rate of $8 \mathrm{~L}^{-1}$, the larvae survived in the former whereas complete mortality was observed in the smaller tank though appropriate food organisms were present to promote growth and survival in both the tanks (Wittenrich et al., 2012). The above observation and several studies indicated that in addition to other factors mentioned, tank size and stocking density are two crucial factors which affect the survival of damsel fish larvae.

The larval body showed notable development from the 5th day onwards, which included an increase in the body width, the appearance of pigmentation, and the functioning of a full-fledged digestive system. Similar observations on pigmentation were made in A. saxatilis larvae, which showed the appearance of pigmentation on the 5th to 7th day (Alshuth et al., 1998). The yolk was also exhausted by the 3-4th day in A. saxatilis along with the appearance of a welldeveloped digestive system.

In N. nemurus by the 10th day, fin separation was evident but in A. saxatilis, the caudal rays had just begun to make an appearance and in N. nemurus, most of the larvae had undergone notochord flexion, similar observations were made in the A. saxatilis larvae. In $\mathrm{N}$. nemurus, the larval body was characterized by stellate melanophores, a similar pattern of pigmentation was observed in A. saxatilis. Pomacentrids also lack elongate fin spines and the fin elements or scales develop precociously (Murphy et al., 2007). On the 15th day, fin separation has just been completed in $N$. nemurus whereas in $A$. saxatilis fin separation can be witnessed on the 17 th day. In N. nemurus, the fin pigmentation developed on spinous dorsal fin by the 21st day whereas in Yellowtail damselfish, M. chrysurus it took about 2127 days to complete the pigmentation in the spinous dorsal fin (Wellington \& Victor, 1989). The striping pattern was evident in A. saxatilis from the 21st day onwards whereas in N. nemurus it took about 35 days to attain the adult colouration.

In sergeant major, $A$. saxatilis the feeding schedule included $B$. plicatilis, 35-90 $\mu \mathrm{m}$ size-sorted zooplankton, 90-250 $\mu \mathrm{m}$ sizesorted zooplankton, $12 \mathrm{hr}$ Artemia sp., and $48 \mathrm{hr}$ Artemia sp., (Wittenrich et al., 2012). Neopomacentrus cyanomos was given zooplankton segregated by passing through a sieve of mesh size $500 \mu \mathrm{m}$ and then retained in the sieve of $20-\mu \mathrm{m}$ mesh size, plankton could be replaced successfully by $P$. serricaudatus from the 10th day onwards and from the 15th day onwards freshly hatched Artemia nauplii were given to the larvae. No mortality was reported after the 15th day. Pellet feed of size $300 \mu \mathrm{m}$ and boiled mussel meat were given to the larvae from the 30th day onwards (Rohini Krishna et al., 2016). In the present study, the larvae were divided into three groups and in T1 from day 0 to 8 the larva was fed with the copepod Parvocalanus nauplii and from 6 to 18th day on rotifer and then from 16th day on Artemia nauplii. Mussel meat was given from 35th day onwards.

The composition of live feed in the rearing tank affects the larval survival and performance. This was demonstrated by the splitting of the larvae into three experimental groups. From day 1 to 5 , fish were fed with copepods in T1, enriched rotifer (B. plicatilis) in T2, and non-enriched rotifer in T3. From this, we can understand the importance of the starter feed in the larval survival and growth. Even though rotifers are not suitable to be given as a starter feed, they can be successfully employed to feed the larvae from the 6th or 7th day onwards, which is illustrated by the survival of the larvae in the first tank. Although proper prey items are indispensable for larval survival, many other factors influence larval survival such as photoperiod (Arvedlund et al., 2000; Olivotto, Cardinali, Barbaresi, Maradonna, \& Carnevali, 2003), temperature and salinity (Hart, Hutchinson, \& Purser, 1996), development of appropriate digestive enzymes (Kolkovski, Tandler, Kissil, \& Gertler, 1993), development of the feeding mechanism (Wittenrich, 2007), rearing tank design (Büke, Özden, \& Arslan, 2005), and flow field (Sakakura, Shiotani, Chuda, \& Hagiwara, 2007).

The survival rate was found to be $4.9 \pm 2.0$. Similar (3\%-5\%) survival rates were obtained in dusky grouper Epinephelus marginatus, which was fed on copepods (Kerber, Azevedo Silva, Antonio dos Santos, \& Sanches, 2012). Copepod nauplii can be used as a starter feed for larvae of marine fish because of their small size and high nutritional value (McKinnon et al., 2003). Lower survival (2\%) was obtained in giant grouper Epinephelus lanceolatus in which a mix of calanoid copepods ( $P$. crassirostris) (0.5-3.0 per $\mathrm{ml}$ ) and enriched S-type rotifers (10 per $\mathrm{ml}$ ) was given to the fish larvae at 3 days per hatch (Armando, Adam, \& Kevin, 2014). Other pomacentrids such as clown fish have larger eggs and can be reared using rotifers. Amphiprion nigripes was fed on rotifer from 0 to $15 \mathrm{dph}$ (Anil et al., 2012). The super small (ss) strain of rotifers has been used successfully as a starter feed in larviculture of altricial fish larvae like groupers, so attempts can be made to use such ss strains of rotifers as starter feed for damsel fish larvae. Damsel fish of genus Abudefduf have larger eggs, longer incubation time and bigger larvae so they could be reared using rotifers during the initial days of hatching. In Sergeant major, A. saxatilis 6\% survival was obtained by a diet of rotifers and size-sorted copepod dominated zooplankton (Wittenrich et al., 2012). Adding adult copepods in the present study ensured the availability of first naupliar stages (40$45 \mu \mathrm{m}$ ) for the fish larvae to feed upon.

\section{ACKNOWLEDGMENTS}

We would like to extend our warm gratitude to $\mathrm{Dr}$ A. Gopalakrishnan, Director, ICAR-Central Marine Fisheries Research Institute, Kochi, for the permission granted and facilities provided. I would also like to thank Dr Santhosh, Principal Scientist, Vizhinjam Research Centre of ICAR-CMFRI for providing the stock culture of Parvocalanus crassrostris. We would like to thank all the staff members of Vizhinjam Research Centre of ICAR-CMFRI for all support.

\section{ORCID}

Manoharan Pillai VasanthaRohini Krishna (iD http://orcid.org/00000002-2073-5763 


\section{REFERENCES}

Allen, G. R. (1991). Damselfishes of the world (p. 271). Melle, Germany: Mergus Publishers.

Alshuth, S. R., Tucker, J. W. Jr, \& Hatley, J. (1998). Egg and larval development of laboratory-reared sergeant major, Abudefduf saxatilis (Pisces, Pomacentridae). Bulletin of Marine Science, 62, 121-133.

Anil, M. K., Santhosh, B., Prasad, O., \& George, R. M. (2012). Broodstock development and breeding of black-finned anemonefish Amphiprion nigripes Regan, 1908 under captive conditions. Indian Journal of Fisheries, 59, 77-82.

Armando, G.-O., Adam, D., \& Kevin, H. (2014). Feeding hatchery-produced larvae of the giant grouper Epinephelus lanceolatus. Hatchery technology for high quality juvenile production. Proceedings of the 40th U.S.-Japan Aquaculture Panel Symposium, Honolulu, Hawaii.

Arvedlund, M., McCormick, M. I., \& Ainsworth, T. (2000). Effects of photoperiod on growth of larvae and juveniles of the anemonefish Amphiprion melanopus. Naga - the ICLARM Quarterly, 23, 19-23.

Berkeley, S. A., Chapman, C., \& Sogard, S. M. (2004). Maternal age as a determinant of larval growth and survival in a marine fish, Sebastes melanops. Ecology, 85, 1258-1264. https://doi.org/10.1890/03-0706

Bermudes, M., \& Ritar, A. J. (1999). Effects of temperature on the embryonic development of the striped trumpeter (Latris lineata Bloch and Schneider, 1801). Aquaculture, 176, 245-255. https://doi.org/10. 1016/S0044-8486(99)00117-9

Brinley, F. J. (1939). Spawning habits and development of Beaugregory (Pomacentrus leucostictus). Copeia, 1939, 185-188. https://doi.org/10. 2307/1436876

Büke, E., Özden, O., \& Arslan, T. (2005). Effects of different tank types on growth and survival of European sea bass, Dicentrarchus labrax Linneaus, 1758. Su Ürünleri Dergisi, 22, 311-316.

Das, T., Pal, A. K., Chakraborty, S. K., Manush, S. M., Dalvi, R. S., Sarma, K., \& Mukherjee, S. C. (2006). Thermal dependence of embryonic development and hatching rate in Labeo rohita (Hamilton, 1822). Aquaculture, 255, 536-541. https://doi.org/10.1016/j.aquaculture. 2006.01.013

FAO. (2014). Fisheries and aquaculture statistics and information branch. Global production and trade 1976-2011. Retrieved from https:// www.fao.org/fishery/statistics/en

Fisher, R., Bellwood, D. R., \& Job, S. D. (2000). Development of swimming abilities in reef fish larvae. Marine Ecology Progress Series, 202, 163-173. https://doi.org/10.3354/meps202163

Gopakumar, G., Madhu, K., Madhu, R., Ignatius, B., Krishnan, L., \& Mathew, G. (2009). Broodstock development, breeding and seed production of selected marine food fishes and ornamental fishes. Marine Fisheries Information Service Technical \& Extension Service, 201, 1-9.

Gopakumar, G., Santhosi, I., \& Ramamurthy, N. (2009). Breeding and larviculture of the Sapphire devil damselfish Chrysiptera cyanea. Journal of Marine Biological Association of India, 51, 130-136.

Goulet, D. (1995). Temporal patterns of reproduction in the Red Sea damselfish Amblyglyphidodon leucogaster. Bulletin of Marine Science, 57, 582-595.

Green, B. S., \& McCormick, M. I. (2005). Maternal and paternal effects determine size, growth and performance in larvae of a tropical reef fish. Marine Ecological Progress Service, 289, 263-272. https://doi.org/ $10.3354 /$ meps 289263

Green, E. (2003). International trade in marine aquarium species: Using the global marine aquarium database. In J. C. Cato, \& C. L. Brown (Eds.), Marine ornamental species: Collection, culture, and conservation (pp. 31-47). Ames, IA: lowa State Press.

Hart, P. R., Hutchinson, W. G., \& Purser, G. J. (1996). Effects of photoperiod, temperature and salinity on hatchery-reared larvae of the greenback flounder (Rhombosolea tapirina Günther, 1862). Aquaculture, 144, 303-311. https://doi.org/10.1016/0044-8486(96)01305-1
Holt, G. J. (2003). Research on culturing the early life history stages of marine ornamental species. In J. C. Cato, \& C. L. Brown (Eds.), Marine ornamental species: Collection, culture and conservation (pp. 251-254). Ames, IA: lowa State Press.

Holt, G. J., \& Riley, C. M. (2001). Laboratory spawning of coral reef fishes: Effects of temperature and photoperiod. Proceedings of the 28th U.S-Japan Natural Resources Aquaculture Panel: Spawning and Maturation of Aquaculture Species. UJNR Technical Report, 28, 3338.

Jagadis, I., Ignatius, B., Kandasami, D., \& Khan, M. A. (2006). Embryonic and larval development of honeycomb grouper Epinephelus merra, Bloch. Aquaculture Research, 37, 1140-1145. https://doi.org/10. 1111/j.1365-2109.2006.01538.x

Kavanagh, K. D. (1996). The early life history of the brooding damselfish Acanthochromis polycanthus: Effects of environment and ancestry. $\mathrm{PhD}$ thesis, James Cook University of North Queensland.

Kazuyuki, S., Hisashi, K., \& Shogoro, K. (1988). Changes in low temperature tolerance of the eggs of certain marine fish during embryonic development. Comparative Biochemistry and Physiology Part A: Physiology, 91, 183-187. https://doi.org/10.1016/0300-9629(88)91614-3

Kerber, C. E., Azevedo Silva, H. K., Antonio dos Santos, P., \& Sanches, E. G. (2012). Reproduction and larviculture of dusky grouper Epinephelus marginatus (Lowe 1834) in Brazil. Journal of Agricultural Science and Technology, 2, 229-234.

Kolkovski, S., Tandler, A., Kissil, G. W., \& Gertler, A. (1993). The effects of dietary exogenous digestive enzymes on ingestion, assimilation, growth and survival of gilthead seabream (Sparus aurata, Linnaeus) larvae. Fish Physiology and Biochemistry, 12, 203-209.

Ma, Z., Guo, H., Zhang, N., \& Bai, Z. (2013). State of art for larval rearing of grouper. International Journal of Aquaculture, 13, 63-72.

Madhu, K., Madhu, R., \& Retheesh, T. (2012). Broodstock development, breeding, embryonic development and larviculture of spine-cheek anemonefish, Premnas biaculeatus (Bloch, 1790). Indian Journal of Fisheries, 59, 65-75.

McKinnon, A. D., Duggan, S., Nichols, P. D., Rimmer, M. A., Semmens, G., \& Robino, B. (2003). The potential of tropical Paracalanid copepods as live feeds in aquaculture. Aquaculture, 223, 89-106. https://doi. org/10.1016/S0044-8486(03)00161-3

Miranda, A., Cal, R. M., \& Iglesias, J. (1990). Effect of temperature on the development of eggs and larvae of sardine Sardina pilchardus, Walbaum in captivity. Journal of Experimental Marine Biology and Ecology, 140, 69-77. https://doi.org/10.1016/0022-0981(90)90082-N

Moe, M. A. (1997). Spawning and rearing the large angelfish Pomacanthus sp. Aquarium Frontiers, 5(6), 14-24.

Molina, L., \& Segade, A. (2012). Aquaculture as a potential support of marine aquarium fish trade sustainability. WIT Transactions on Ecology and the Environment, 148, 15-25.

Moorhead, J. A., \& Zeng, C. (2010). Development of captive breeding techniques for marine ornamental fish. Reviews in Fisheries Science, 18, 315-343.

Moran, D., Smith, C. K., Gara, B., \& Poortenaar, C. W. (2007). Reproductive behaviour and early development in yellowtail kingfish (Seriola lalandi Valenciennes 1833). Aquaculture, 262, 95-104. https://doi. org/10.1016/j.aquaculture.2006.10.005

Murphy, M. F., Leis, J. M., \& Kavanagh, K. D. (2007). Larval development of the Ambon damselfish, Pomacentrus amboinensis, with a summary of Pomacentrid development. Journal of Fish Biology, 71, 569-584. https://doi.org/10.1111/j.1095-8649.2007.01524.x

Myers, R. F. (1991). Micronesian reef fishes (2nd ed., p. 298). Barrigada, Guam: Coral Graphics.

Myrberg, A. Jr, Brahy, D., \& Emery, A. R. (1967). Field observations on the reproduction of the damselfish, Chromis multilineata (Pomacentridae) with additional notes on general behaviour. Copeia, 4, 819-827.

Olivotto, I., Alessio, Z., Arianna, R., Beatrice, M. B., Matteo, A., \& Carnevali, O. (2005). Breeding, rearing and feeding studies in the cleaner 
goby Gobiosoma evelynae. Aquaculture, 250, 175-182. https://doi. org/10.1016/j.aquaculture.2005.02.057

Olivotto, I., Cardinali, M., Barbaresi, L., Maradonna, F., \& Carnevali, O. (2003). Coral reef fish breeding: The secrets of each species. Aquaculture, 224, 69-78. https://doi.org/10.1016/S0044-8486(03) 00207-2

Olivotto, I., \& Geffroy, B. (2017). Clownfish Reproduction. In R. Calado, I. Olivotto, M. Planas Oliver, \& G. Joan Holt (Eds.), Marine Ornamental Species Aquaculture (pp. 177-199). Oxford, UK: Wiley-Blackwell.

Olivotto, I., Rollo, A., Sulpizio, R., Avella, M., Tosti, L., \& Carnevali, O. (2006). Breeding and rearing the Sunrise Dottyback Pseudochromis flavivertex: The importance of live prey enrichment during larval development. Aquaculture, 255, 480-487. https://doi.org/10.1016/j.a quaculture.2006.01.007

Ostrowski, A. C., \& Laidley, C. W. (2004). Application of marine food fish techniques in marine ornamental aquaculture: Reproduction and larval first feeding. Aquar Sci Cons, 3, 191-204.

Potthoff, T., Kelley, S., Saksena, V., Moe, M., \& Young, F. (1987). Description of larval and juvenile Yellowtail damselfish, Microspathodon chrysurus, Pomacentridae, and their osteological development. Bulletin of Marine Science, 40, 330-375.

Rhyne, A. L., Tlusty, M. F., Schofield, P. J., Kaufman, L., Morris, J. A. Jr, \& Bruckner, A. W. (2012). Revealing the appetite of the marine aquarium fish trade: The volume and biodiversity of fish imported into the United States. PLoS ONE, 7, e35808. https://doi.org/10.1371/journal. pone.0035808

Rohini Krishna, M. V., Anil, M. K., Neethu Raj, P., \& Santhosh, B. (2016). Seed production and growth of Neopomacentrus cyanomos (Bleeker, 1856) in captivity. Indian Journal of Fisheries, 63, 50-56. https://doi. org/10.21077/ijf.2016.63.3.55058-06

Sakakura, Y., Shiotani, S., Chuda, H., \& Hagiwara, A. (2007). Flow field control for larviculture of the seven-band grouper Epinephelus septemfasciatus. Aquaculture, 268, 209-215. https://doi.org/10.1016/j.aquac ulture.2007.04.042
Schreck, C. B., Contreras-Sanzhez, W., \& Fitzpatrick, M. (2001). Effects of stress on fish reproduction, gamete quality, and progeny. Aquaculture, 197, 3-24. https://doi.org/10.1016/S0044-8486(01)00580-4

Thornhill, D. J. (2012). Ecological impacts and practices of the coral reef wildlife trade (p. 179). Washington, DC: Defenders of Wildlife.

Thresher, R. E. (1984). Reproduction in reef fishes (p. 399). Neptune City, NJ: TFH Publications.

Wabnitz, C., Taylor, M., Green, E., \& Razak, T. (2003). From oceans to aquarium: The global trade in marine ornamental species. Cambridge, UK: United Nations Environment Programme - World Conservation Monitoring Centre.

Wellington, G. M., \& Victor, B. C. (1989). Planktonic larval duration of one hundred species of Pacific and Atlantic damselfishes (Pomacentridae). Marine Biology, 101, 557-567. https://doi.org/10.1007/ BF00541659

Wittenrich, M. L. (2007). Variation in the development of the feeding mechanism and feeding performance in coral reef fishes. Bulletin of Marine Science, 62, 121-133.

Wittenrich, M. L., Turingan, R. G., \& Cassiano, E. J. (2012). Rearing tank size effects feeding performance, growth, and survival of sergeant major, Abudefduf saxatilis larvae. AACL Bioflux, 5, 393-402.

Yousif, O. M., Kumar, K., Balamurugan, M., Hozifa, V., \& Sagir, A. (2016). Fingerling production of orange-spotted grouper on Abu Al Abyad Island, United Arab Emirates. World Aquaculture, 39-41.

How to cite this article: Rohini Krishna MV, Anil MK, Gomathi P, Raheem PK, Neethu Raj P. Studies on the broodstock production and larval rearing of Coral demoiselle Neopomacentrus nemurus (Bleeker 1857). Aquac Res.

2018;00:1-11. https://doi.org/10.1111/are.13898 